\title{
The Draft Common Frame of Reference: how to improve it?
}

Citation for published version (APA):

Smits, J. M. (2010). The Draft Common Frame of Reference: how to improve it? In H-W. Micklitz, \& F. Cafaggi (Eds.), European Private Law after the Common Frame of Reference (pp. 90-100). Edward Elgar Publishing. https://doi.org/10.4337/9781849805391.00010

Document status and date:

Published: 01/01/2010

DOI:

10.4337/9781849805391.00010

Document Version:

Accepted author manuscript (Peer reviewed / editorial board version)

\section{Please check the document version of this publication:}

- A submitted manuscript is the version of the article upon submission and before peer-review. There can be important differences between the submitted version and the official published version of record.

People interested in the research are advised to contact the author for the final version of the publication, or visit the DOI to the publisher's website.

- The final author version and the galley proof are versions of the publication after peer review.

- The final published version features the final layout of the paper including the volume, issue and page numbers.

Link to publication

\footnotetext{
General rights rights.

- You may freely distribute the URL identifying the publication in the public portal. please follow below link for the End User Agreement:

www.umlib.nl/taverne-license

Take down policy

If you believe that this document breaches copyright please contact us at:

repository@maastrichtuniversity.nl

providing details and we will investigate your claim.
}

Copyright and moral rights for the publications made accessible in the public portal are retained by the authors and/or other copyright owners and it is a condition of accessing publications that users recognise and abide by the legal requirements associated with these

- Users may download and print one copy of any publication from the public portal for the purpose of private study or research.

- You may not further distribute the material or use it for any profit-making activity or commercial gain

If the publication is distributed under the terms of Article $25 \mathrm{fa}$ of the Dutch Copyright Act, indicated by the "Taverne" license above, 


\title{
5. The Draft Common Frame of Reference: how to improve it?
}

\author{
Jan M. Smits*
}

\section{INTRODUCTION}

The aim of this contribution is to discuss the view of law and lawmaking underlying the Draft Common Frame of Reference (DCFR). ${ }^{1}$ It claims that the DCFR suffers from so-called methodological nationalism and therefore fails to adopt the right approach to dealing with private law in the European Union. The theoretical analysis is followed by some concrete suggestions on how to improve the DCFR so that it better meets its intended functions.

Section 2 offers a brief introduction to the DCFR. It is followed by an account of what is meant by 'methodological nationalism' and how this is applied in law (section 3). Sections 4, 5 and 6 subsequently offer an analysis of why the DCFR is to be qualified as an example of this methodology. This does not mean that the DCFR cannot fulfil a useful role in the present debate, but it may have to be a different role from that envisaged by the drafters. Sections 6 and 7 therefore offer an alternative and differentiated perspective on the way forward in European contract law.

\section{THE DCFR: BACKGROUND AND PURPOSE}

The presentation of the DCFR to the European Commission on 28 December 2007 was the result of four years of work by the Study Group on a European Civil Code and the Research Group on the Existing EC Private Law (the

* This chapter benefits from discussion at a workshop at the European University Institute (29 February-1 March 2008). It is a slightly amended and elaborated version of the paper presented at the SECOLA Conference on Fifty Years of European Contract Law (Barcelona, 6-7 June 2008).

Von Bar, C., E. Clive and H. Schulte-Nölke (eds) (2008), Principles, Definitions and Model Rules of European Private Law: Draft Common Frame of Reference, Interim Outline Edition, Munich: Sellier. 
'acquis group'). ${ }^{2}$ In its Communication on European Contract Law of 2004, ${ }^{3}$ the European Commission indicated that 'definitions, principles and model rules' for a European contract law would have to be prepared in order to improve the quality and overall consistency of the existing acquis in this area. The present draft is the provisional result of this project and will be followed by a final version in 2008 .

The DCFR consists of ten 'books', dealing with general provisions (Book I), contracts and other juridical acts (Book II), obligations and corresponding rights (Book III), specific contracts (Book IV), benevolent intervention in another's affairs (Book V), tort law (Book VI) and unjustified enrichment (Book VII). The books on acquisition and loss of ownership in movables (Book VIII), security rights in movables (Book IX) and trusts (Book X) are not yet published. The two annexes contain a list of definitions and rules on computation of time.

According to its drafters, the Common Frame of Reference has several purposes. ${ }^{4}$ First (and foremost), it is a possible model for a 'political CFR': the current text is presented as an academic one and the European Commission has to decide whether it will use it as a building block when revising the present acquis or when drafting new rules. Second, the drafters regard the CFR as standing on its own as an academic text for legal science and teaching. They highlight that the DCFR will promote knowledge of private law in the jurisdictions of the European Union, and will in particular 'help to show how much national private laws resemble one another and have provided mutual stimulus for development and indeed how much those laws may be regarded as regional manifestations of an overall common European legacy'. ${ }^{5}$ Third, in the same vein as the previously published Principles of European Contract Law, the CFR can be a source of inspiration for national courts, the European Court of Justice and national legislators. Finally, it may form the basis for an optional contract code. ${ }^{6}$

It should be reiterated that, in the view of the European Commission, the main aim of the final CFR is to serve as a 'tool box' for the European legislator:' it can, 'where appropriate', ${ }^{8}$ make use of the CFR to draft new directives

2 These groups are the most important members of the Joint Network on European Private Law (CoPECL).

3 Communication on European Contract Law and the Revision of the Acquis: the Way Forward, COM(2004)651 final, OJ EC 2005, C 14/6.

$4 \operatorname{DCFR}(2008), 6 \mathrm{ff}$.

5 DCFR (2008), 6.

$6 \operatorname{DCFR}(2008), 37$.

7 Communication (2004), 14.

8 Communication (2004), 3. 
or to review the existing acquis. The instrument is not in any way binding upon the European legislator or the Member States, ${ }^{9}$ but should derive its authority from the quality of its provisions.

When assessing the DCFR, we should keep in mind that the present text contains only the provisions and not the illustrations and comments that make the Principles of European Contract Law such a useful source of inspiration. However, much of the preparatory work can be found in the series Principles of European Law ${ }^{10}$ as published by the Study Group on a European Civil Code and in the so-called Acquis Principles (ACQP), ${ }^{11}$ which were designed to systematise the existing directives in the field of private law.

\section{METHODOLOGICAL NATIONALISM AND LAW}

How to evaluate the DCFR? The Draft can be considered from the angle of different theoretical frameworks. The perspective chosen in this contribution is the angle of so-called methodological nationalism. This term was coined for the first time by the sociologist Herminio Martins. ${ }^{12}$ It refers to the idea that the process of nation-state building fundamentally shaped our way of thinking, even to such an extent that the division of societies along the lines of nationstates is seen as the natural form of organising things. ${ }^{13}$ Methodological nationalism can therefore be described as the assumption that the nation, state or national society is the natural social and political form of the modern world. ${ }^{14}$ There are various modes of such methodological nationalism; one of them, in the words of Wimmer and Schiller, is to take 'national discourses, agendas, loyalties and histories for granted, without problematizing them or making them an object of an analysis in its own right'. ${ }^{15}$

9 Communication (2004), 6.

10 Published by Sellier Publishers (Munich) from 2006 onwards.

11 Research Group on the Existing EC Private Law (2007), Principles of the Existing EC Contract Law (Acquis Principles), Vol. I: Contract: Pre-contractual Obligations, Conclusion of Contract, Unfair Terms, Munich: Sellier, on which Jansen, N. and R. Zimmermann (2007), 'Grundregeln des bestehenden Gemeinschafts privatrechts?', 62 Juristenzeitung 1113. Vol. II on Performance, Non-Performance and Remedies is announced for 2008.

12 Martins, H. (1974), 'Time and Theory in Sociology', in: J. Rex, Approaches to Sociology, London: Routledge \& Kegan, 246, at 276.

13 See Wimmer, A. and N. Glick Schiller (2002), 'Methodological Nationalism and Beyond: Nation-State Building, Migration and the Social Sciences', 2 Global Networks 301, at 304.

14 See Wimmer and Schiller (2002), at 302.

15 Wimmer and Schiller (2002), at 304. 
It is no surprise that the legal domain in particular has been largely affected by methodological nationalism. Nations and their products in the form of national legislation and case law are usually seen as the basic units of analysis in legal scholarship. The way we think about law, both as to its validity, enforcement and legitimation, is largely shaped by this method. At a very general level, even the mere distinction of national and international legal orders is an example of this way of thinking, as is the existence of the discipline of comparative law. ${ }^{16}$ But at a more concrete level, methodological nationalism may prevent us from looking beyond traditional concepts. ${ }^{17}$ Ulrich Beck is right when he says that increasing denationalisation and transnationalisation should lead us to a reconceptualisation of law within a new cosmopolitan framework, in order to avoid our discipline becoming 'a museum of antiquated ideas'.18

The point being made here is that when we think about law and the requirements it should meet, we (often implicitly) make use of concepts that were developed for law in the nation-state: our traditional way of thinking, developed for law in a national society, is then transplanted to the European or global level. The finding that this is wrong is clearly part of the debate in the field of European law ${ }^{19}$ and, albeit to a lesser extent, in constitutional law, ${ }^{20}$ but it is much less debated in other classical areas of law such as private law. ${ }^{21}$ Often, the conceptual legal framework is transplanted to the European level without much deliberation of whether this is the proper approach. Also in drafting the CFR, this issue seems not to have been discussed: the structure and contents of the Draft are remarkably similar to those of a national civil

16 Cf. Joerges, C. (2004), 'The Challenges of Europeanization in the Realm of Private Law: A Plea For a New Legal Discipline', 14 Duke J. Comp. Int. L. 149, at 160.

17 Cf. Beck, U. (2003), 'Toward a New Critical Theory with a Cosmopolitan Intent', 10 Constellations 453, at 456: methodological nationalism prevents us from looking beyond the 'traditional conceptualisations of terms and the construction of borders between the 'national' and the 'international', domestic and foreign politics, or society and the state'.

18 Beck (2003), at 458.

19 I only need to refer to the elaborate discussion about the best way to characterise the European Union (not as a federation or as an international organisation, but as a sui generis type of entity).

20 Building on Habermas' concept of a 'postnational constellation' in which traditional democratic processes have to take on new forms: see Habermas, J. (2001), The Postnational Constellation: Political Essays, Cambridge Mass: Harvard University Press.

21 Notable exceptions are Joerges, C. (2004), 149 ff., Michaels, R. (2005), 'Welche Globalisierung für das Recht? Welches Recht für die Globalisierung?', RabelsZ, 525 ff. and the contributions to Cafaggi, F. (ed.) (2006), The Institutional Framework of European Private Law, Oxford: OUP. 
code, even though its function cannot in any way be compared to it, even in the view of the drafters.

In the following sections, I will discuss three features of the DCFR where this methodological nationalism comes to the surface. Implied in this qualification is that the DCFR takes too little into account that what is best at the national level may not be optimal at the European level. ${ }^{22}$ The features I am interested in deal with the idea of a comprehensive codification of private law as such (section 4), the way in which the relevant rules are chosen (section 5) and the best way to represent law at a level other than that of the nation-state (section 6).

\section{COMPREHENSIVE CODIFICATION OR A MULTI- LAYERED EUROPEAN PRIVATE LAW?}

The suggestion that the idea of codification is closely related to the nationstate needs little explaining: historically, codification of private law has been an expression of national identity. In the same vein, one needs little imagination to see that the ideal of a uniform private law laid down in one comprehensive text is closely related to two other goals: the quests for legal certainty and equality. ${ }^{23}$ The question now is whether these goals are best attained at the supra-national level by drafting a text that closely resembles the format of a national civil code, as is the case with the DCFR. Not only in terms of the topics addressed, but also with regard to its structure and the style of its provisions, the Draft looks like a national code. But can we really transplant the traditional features of a civil code into a text for the European Union?

The answer to this question can only be given if we realise that the function of the CFR is different from the traditional function of a national code. The drafters submit that the CFR will primarily be a 'toolbox' for new European legislation or a source of inspiration for national courts and legislators. Closest to our idea of a national code is that it may form the basis for an optional code. But if full harmonisation replacing national jurisdictions is not the aim of the CFR, this must mean something for the structure and substance of this instrument. Two things should be taken into account.

First, we should recognise that private law at the European level will continue to flow from various sources: there will be a continuous co-habitation

22 I have been critical about the entire project before: see Smits, J.M. (2006), 'European Private Law: a Plea for a Spontaneous Legal Order', in: D. Curtin, et al, European Integration and Law, Antwerp-Oxford: Intersentia.

23 Cf. Jansen, N. (2004), Binnenmarkt, Privatrecht und europäische Identität, Tübingen: Mohr Siebeck, 20. 
of private law emanating from both national and European sources, which will also consist of private regulation. ${ }^{24}$ This multi-layered structure of European private law prompts the question at which regulatory level issues are best regulated. The entire private law system can in any event no longer be governed by only one piece of legislation, ${ }^{25}$ as this would be contrary to the allocation of normative powers between the Member States and the European Union. ${ }^{26}$ The DCFR seems to shows little evidence of this insight. Thus, one could well argue that contract law is best regulated at the European level because of its close relationship to the European internal market, whereas e.g. the law of restitution, which serves the role of correcting and supplementing the existing law of obligations, best fulfils its function at the national level. ${ }^{27}$ In Stephen Swann's phrase, we are 'constructing a castle in the air' wherever there are no common foundations beneath a European law of obligations. ${ }^{28}$

Second, any attempt to redraft present European private law should take into account the rules already in existence. Codification at the national level is often associated with starting afresh and abolishing the 'old' law, but this cannot be the case in the European Union. In this sense, it seems that the present DCFR is far removed from the (sector-specific and fragmentary) European acquis. The primary motivation for the project was the European Commission's desire to revise the existing European directives in the field of private law with a view to dealing with their fragmentary, inconsistent and less than fully effective character. If one judges the DCFR in terms of this objective, some of the proposed

24 On private regulation at the European and supranational level see e.g. Cafaggi, F. (ed.) (2006), Reframing Self-regulation in European Private Law, The Hague: Kluwer; Schiek, D. (2007), 'Private Rule-making and European Governance: Issues of Legitimacy', European Law Review 443 and Zumbansen, P. (2007), The Law of Society: Governance Through Contract, CLPE Research Paper 2/2007.

25 Cf. Cafaggi, F. (2006), 'Introduction', in: id. (ed), The Institutional Framework of European Private Law, Oxford: OUP, 1 and Cafaggi, F. (2008), 'The Making of European Private Law: Governance Design', in: F. Cafaggi, and H. Muir Watt, Making European Private Law: Governance Design, Cheltenham: Edward Elgar, 289.

26 All traditional codifications were declared to be exclusive: they were the only source of law. See for a thorough analysis Van den Berg, P.A.J. (2007), The Politics of European Codification: A History of the Unification of Law in France, Prussia, the Austrian Monarchy and the Netherlands, Groningen: Europa Law Publishing.

27 See Smits, J.M. (2008), 'A European Law on Unjustified Enrichment? A Critical View of the Law of Restitution in the Draft Common Frame of Reference', in: A. Vaquer (ed.), European Private Law Beyond the Common Frame of Reference, Groningen: Europa Law Publishing, 153.

28 Swann, S. (2005), 'The Structure of Liability for Unjustified Enrichment: First Proposals of the Study Group on a European Civil Code', in: R. Zimmermann (ed.), Grundstrukturen eines Europäischen Bereicherungsrecht, Tübingen: Mohr Siebeck, 268. 
provisions will indeed yield improvement (e.g. the draft deals with duties to provide information to the consumer, the effects of exercising the right of withdrawal and the creation of a uniform withdrawal period of 14 days). But most of the provisions do not relate to the existing acquis at all. ${ }^{29}$ To be fair, the drafters do realise this by presenting their text as an 'academic CFR', a scholarly text which is not politically legitimised and which at best could provide the basis for a 'political CFR' to be drafted by the European Commission. But the Commission itself has already indicated that it will aim primarily at a revision of eight existing directives. ${ }^{30}$ Provisions on the law of obligations in general (including negotiotum gestio and unjustified enrichment) and on some specific contracts (which are not covered by directives at all) do not fit this purpose. In this respect, it seems that part of the work done by the Study Group no longer reflects present reality. ${ }^{31}$

\section{CHOICE OF THE RELEVANT RULES}

A second feature of national codifications is that there is usually little doubt about what the relevant rules should be and who should choose them. This is because at the national level there is usually a generally accepted criterion for deciding which rules are to be incorporated in the code, and because there is a generally accepted procedure for adopting such rules (in most cases this is a national democratic decision process). At the European level such consensus is lacking. ${ }^{32}$ This makes it all the more important to employ a clear method when deciding which rules should be part of the CFR and who should adopt the final text.

According to the drafters of the CFR, its provisions are based on a comparative analysis of the law of the Member States and the applicable European law. ${ }^{33}$ But this method is not very convincing if one does not know how this

29 Surprisingly, neither is the case law of the European Court of Justice codified in any way, whereas one would have expected a codification of the doctrine of state liability on the basis of Francovich and Brasserie.

30 Green paper on the revision of the consumer acquis of 8 February 2007, $\operatorname{COM}(2006) 744$ final. Also see Second progress report on the CFR of 25 July 2007, $\operatorname{COM}(2007) 447$ final.

31 The following remark (DCFR (2008), 10) is therefore surprising: '[w]hether particular rules might be used as a model for early legislation, for example, for the improvement of the internal coherence of the acquis communautaire ... is for others to decide'.

32 Cf., Study Group on Social Justice in European Private Law (2004), 'Social Justice in European Contract Law: a Manifesto', 10 European Law Journal 653.

33 DCFR (2008), 12. 
comparative method was applied: did one look for the common denominator of the jurisdictions involved ${ }^{34}$ or for the solution considered to be the 'better' one (and, if so, for what reason)? Discussion about the contents of the provisions is difficult if the drafters do not explain what motivated such choices. The following comment seems to indicate the approach adopted: ${ }^{35}$

the model rules of course build on ... underlying principles ... . It would be possible to include in the DCFR a separate part which states these basic values and suggests factors that the legislator should bear in mind when seeking to strike a balance between them. For example, this part could be formulated as recitals, i.e. an introductory list of reasons for the essential substance of the following text ... . If this idea is thought to be useful, a fuller version could be developed at a later stage. It must be conceded, however, that, taken in isolation, such fundamental principles do not advance matters much at a practical level because of their high level of abstraction. Abstract principles tend to contradict one another. They always have to be weighed up against one another more exactly because only then are optimal outcomes assured.

This suggests that the underlying principles can be discussed afterwards, once the text has already been established. But how can choices already made be justified, if not on basis of (an internal debate about) the underlying values and of how these have to be weighed up against one another? Little help is available from an inventory of the 'core aims of European private law' ${ }^{36}$ so long as the exact relationship between these aims is not made explicit.

\section{HOW TO REPRESENT LAW BEYOND THE NATIONAL STATE?}

In the nation-state, law is usually seen to consist of authoritative rules backed by coercive force which is exercised by legitimately constituted democratic institutions. ${ }^{37}$ The way in which law is usually represented ${ }^{38}$ matches these characteristics: describing law by way of rules pretends that these rules can

34 This is suggested in the CFR (2008), 12, where it says that the CFR 'mediates' between diverging results in the various Member States.

35 DCFR (2008), 9.

36 The authors mention 'justice, freedom, protection of human rights, economic welfare, solidarity and social responsibility', to which they add for European regulation 'promotion of the internal market', 'preservation of cultural and linguistic plurality' and, specifically for the drafting of model rules, the goals of 'rationality, legal certainty, predictability and efficiency'. See DCFR (2008), 13.

37 Cf. Morgan, B. and K. Yeung (2007), An Introduction to Law and Regulation, Cambridge: CUP, 303-304.

38 On the very idea of representing law see Roberts, S.A. (2005), 'After Government? On Representing Law Without the State', 68 Modern Law Review 1. 
create the necessary legal certainty and equality needed to guide those affected by them. In this sense, our understanding of rules is closely related to what these rules can $d o^{39}$ at the national level: they organise society, presuming that the rules came into being in a democratic process and can therefore be enforced by the state institutions. It is thus the national democratic process that enables policy trade-offs to be made transparently and authoritatively. ${ }^{40}$

The question is whether law beyond the national state should be represented in the same way, in particular when, as is the case with the CFR, the aim of the provisions is not directly to influence the conduct of private parties and to be enforced, but primarily to be a source of inspiration. If a text is proposed as an 'academic CFR', should this not influence the way in which the provisions are drafted? The answer must be affirmative: in my view the presentation of legal texts should depend largely on their function. A national civil code needs to be presented in a different way from a set of rules the aim of which is to help improve the existing acquis, or to inspire legislators and courts across Europe or to play a role in legal science and teaching.

It seems to me that this insight has not been sufficiently taken into account in the drafting of the CFR. The authors regard the fact that they were able to distil common rules as evidence of how much national private laws may be regarded as 'regional manifestations of an overall common European legacy'. ${ }^{41} \mathrm{I}$ am also convinced that, in the field of private law, European Member States have a lot in common. But it seems wrong to conclude this merely from being able to draft common rules. Whether jurisdictions resemble one another becomes clear only if all relevant factors are taken into consideration. It may be more important to find uniformity in the use of similar arguments $^{42}$ than in common rules or case decisions: a common text will necessarily be interpreted in different ways in different countries.

This pleads for a differentiated way of representing European private law, depending on whether its function is to create binding rules, offer a source of inspiration or form the first step towards the creation of an optional contract code. $^{43}$

39 Cf. Twining, W. and D.R. Miers (1999), How To Do Things With Rules, 4th edn, Cambridge: CUP.

40 Morgan and Yeung (2007), 305.

41 DCFR (2008), 6.

42 See e.g. Smits, J.M. (2008), 'The German Schuldrechtsmodernisierung and the New Dutch Civil Code: a Study in Parallel', in: O. Remien (ed.), Schuldrechtsmodernisierung und Europäisches Vertragsrecht, Tübingen: Mohr Siebeck, $117 \mathrm{ff}$.

43 Micklitz, H.-W. (2008), The Visible Hand of European Regulatory Private Law: The Transformation of European Private Law from Autonomy to Functionalism in Competition and Regulation, EUI Working Paper 2008/14. 
When it comes to revising the existing acquis, the right approach is to build directly upon the existing directives, making them more coherent and adding some concrete definitions. ${ }^{44}$ This part of the European private law system will resemble national provisions the most. But in the absence of a a single European private law society in which there is a common understanding of the meaning of specific provisions, it is too early to draft provisions in other areas of private law. There, Europeanisation should start with the emergence of a common European legal tradition, for which teaching and legal scholarship are far more important than the drafting of specific rules. Such teaching and scholarship should indeed focus on finding common arguments in European jurisdictions, thus allowing for a competition of legal ideas. ${ }^{45}$ Finally, when creating an optional contract code yet a third perspective is to be adopted. As such codes will have to compete with national jurisdictions, their provisions should certainly not be common denominators of existing national legal systems; instead, they should contain the rules that make this code a good competitor on the market of legal rules. The DCFR, with its many open-ended provisions and unclear policy choices, ${ }^{46}$ is clearly not such a competitor. Again, it is the function of the rules in question that decides how they should be drafted.

\section{THE WAY FORWARD: SUGGESTIONS FOR IMPROVEMENT}

The above discussion of the DCFR is a critical one. Its main point is that it is wrong to draft rules for the CFR in the way we are familiar with at the national level, as if these are rules to be applied in a national legal community. Challenging the regulatory monopoly of states must mean something for the structure and substance of the European rules being put into place. The way forward should therefore consist of a differentiated approach: it depends on the function of the rules in question (revision of the acquis, offering a source of inspiration or creating an optional code) and how they should be presented.

44 With much less generalisation of the existing rules than advocated by the acquis group: cf. Jansen and Zimmermann (2007), $1120 \mathrm{ff}$.

45 Cf. Wilhelmsson, T. (2002), 'The Legal, the Cultural and the Political: Conclusions from Different Perspectives on Harmonisation of European Contract Law', European Business Law Review 551 and Smits, J.M. (1998), 'A European Private Law as a Mixed Legal System', 5 Maastricht Journal of European and Comparative Law 328.

46 See now also Eidenmüller, H., F. Faust, H.C. Grigoleit, N. Jansen, G. Wagner and R. Zimmermann (2008), 'Der Gemeinsame Referenzrahmen für das Europäische Privatrecht', 63 JuristenZeitung 529. 
Concrete suggestions for the improvement of the DCFR follow directly from this functional approach. If we take the present text as a starting point, the following points should be taken into account in adapting it to the real 'toolbox' envisaged by the European Commission:

- the DCFR should make clear how its provisions relate to the existing acquis. As already indicated in section 4, the Commission aims primarily at a revision of the existing directives. This calls for an articulate analysis of this acquis: the DCFR should make abundantly clear which provisions are in line with it and which are not. If provisions of existing directives are not part of the DCFR, it should explain extensively why this is the case.

- in so far as the provisions of the DCFR do not relate to the existing acquis, they should be presented in a more discursive way. Any instrument for scholarship and teaching should be presented as a source of legal ideas, meaning that various options are put forward. In other words: an academic CFR should not make any choices itself, but should offer an inventory of the various solutions. The publication of the present text - without any comments on how choices were made - is useless and can only be seen as an attempt to monopolise the debate.

- if the present DCFR is also to serve as a draft for an optional contract code, it should explain which provisions will be part of such a code. Moreover, it should indicate what criterion is used to select these rules (thus explaining why the optional code is a good competitor compared to national jurisdictions). 